\title{
Kualitas Pembangunan Desa Berbasis Data Desa Presisi (Kasus: Desa Neglasari, Kecamatan Dramaga, Kabupaten Bogor, Jawa Barat)
}

\section{Quality of Village Development Based on Precision Village Dat (Case: Neglasari Village, Dramaga District, Bogor Regency, West Java)}

\author{
Grace Natalia*) dan Sofyan Sjaf
}

Departemen Sains Komunikasi dan Pengembangan Masyarakat, Fakultas Ekologi Manusia, IPB University, Dramaga Bogor 16680, Indonesia

*)E-mail: grace natalia@apps.ipb.ac.id ;

Diterima: 06-12-2021 | Disetujui: 22-12-21 | Publikasi online: 20-01-2022

\begin{abstract}
The facts of the success of village development in Indonesia have not been in accordance with the real conditions and reality. As a result, the quality of village development is still far from expected. The 1945 Constitution states that the quality of village development can be seen from five aspects of people's welfare (kesra): (1) clothing, food, boards; (2) education and culture; (3) health, employment and social security; (4) social life, legal protection and human rights; and (5) infrastructure and the environment. To capture the quality of village development through these 5 aspects of kesra, precision data is needed, considering the various indexes or measurements of the quality of village development in Indonesia based on inaccurate data. This research aims to determine the quality standards of village development based on precision village data, measure the quality of village development based on precision village data, and recommend policies and programs to improve the quality of village development. The research method used is quantitative method with Drone Participatory Mapping (DPM) approach and supported qualitative data through literature study and in-depth interview. The results of this study show that the quality of development of Neglasari Village tends to be low. Recommendations for improving the quality of village development are programs and or policies to increase 8 low category variables and 2 medium category variables.
\end{abstract}

Keywords: Measurement, Precision village data, Quality of village development

\begin{abstract}
ABSTRAK
Fakta-fakta keberhasilan pembangunan desa di Indonesia belum sesuai dengan kondisi dan kenyataan yang sesungguhnya. Alhasil, kualitas pembangunan desa yang diharapkan masih jauh dari harapan. UUD 1945 menyatakan bahwa kualitas pembangunan desa dapat dilihat dari lima aspek kesejahteraan rakyat (kesra): (1) sandang, pangan, papan; (2) pendidikan dan kebudayaan; (3) kesehatan, pekerjaan dan jaminan sosial; (4) kehidupan sosial, perlindungan hukum dan HAM; dan (5) infrastruktur dan lingkungan hidup. Untuk memotret kualitas pembangunan desa melalui 5 aspek kesra ini, dibutuhkan data presisi, mengingat berbagai indeks atau pengukuran kualitas pembangunan desa di Indonesia berbasis data yang tidak akurat. Penelitian ini bertujuan untuk menentukan standar kualitas pembangunan desa berbasis data desa presisi, mengukur kualitas pembangunan desa berbasis data desa presisi, dan merekomendasikan kebijakan dan program perbaikan kualitas pembangunan desa. Metode penelitian yang digunakan adalah metode kuantitatif dengan pendekatan Drone Participatory Mapping (DPM) dan didukung data kualitatif melalui studi literatur, observasi dan wawancara mendalam. Hasil penelitian ini menunjukkan bahwa kualitas pembangunan Desa Neglasari cenderung rendah. Rekomendasi untuk perbaikan kualitas pembangunan desa adalah program dan atau kebijakan peningkatan 8 variabel kategori rendah dan 2 variabel kategori sedang.
\end{abstract}

Kata kunci: Data desa presisi, Kualitas pembangunan desa, Pengukuran. 


\section{PENDAHULUAN}

Pembangunan merupakan usaha untuk memajukan kualitas hidup masyarakat, sehingga dapat mencapai hasil yang diharapkan. Teks pembukaan (UUD 1945) mengamanatkan tujuan dibentuknya Pemerintah Negara Indonesia, yaitu untuk memajukan kesejahteraan umum, atas dasar tersebut, maka agenda Pembangunan Nasional termasuk implementasi yang diprioritaskan negara. Pembangunan Nasional merupakan serangkaian usaha pembangunan berkelanjutan yang meliputi seluruh kehidupan masyarakat, bangsa, dan negara untuk mewujudkan tujuan pembangunan nasional (Sari 2019).

Tujuan pembangunan nasional adalah untuk mencapai kesejahteraan rakyat sebagaimana tersirat pada UUD 1945 Pasal 28 (Amandemen ke-2) dan diperkuat dengan teks pembukaan UUD 1945 mengenai kesejahteraan umum. Kesejahteraan umum dapat dimaknai sebagai tujuan jangka panjang dari pembangunan nasional berbasis desa. Adapun pada UU No. 6 Tahun 2014 tentang Desa bahwa pembangunan desa adalah upaya peningkatan kualitas hidup dan kehidupan untuk kesejahteraan masyarakat Desa.

Menurut Sari (2019), Pembangunan Nasional memiliki beberapa sasaran, seperti: pemulihan ekonomi, kesejahteraan rakyat dan peningkatan kualitas kehidupan beragama dan ketahanan budaya, supremasi hukum dan pemerintahan yang baik, membangun sistem politik yang demokratis dan mempertahankan persatuan dan kesatuan, dan mewujudkan pemerataan pembangunan serta mendorong pembangunan di daerah-daerah.

Oleh karena itu, pembangunan desa membutuhkan standar pengukuran kualitas pembangunan desa. Standar pengukuran ini penting karena bertujuan untuk mengevaluasi pembangunan desa yang dapat menghasilkan kebijakan atau program rekomendasi perbaikan kualitas. Kualitas pembangunan desa, umumnya diukur menggunakan indeks atau standar yang menjadi tolak ukur di dalamnya. Sejauh ini, indeks yang digunakan berupa: (1) Indeks Kesulitan Geografis (IKG); (2) Indeks Pembangunan Desa (IPD), dan (3) Indeks Desa Membangun (IDM).

Persoalan data desa menjadi faktor hadirnya ragam persoalan di pedesaan karena banyaknya data desa yang jauh dari keadaan riil di lapangan. Menurut Sjaf et al. (2020), selama ini desa dan warganya selalu dipandang sebagai objek, padahal partisipasi warga desa sebagai subjek merupakan tonggak penting dalam membangun data desa yang akurat.

Data Desa Presisi (DDP) hadir untuk mengambil peran dalam mewujudkan pembangunan nasional melalui pembangunan kualitas desa berbasis data aktual. Oleh karena itu, penting untuk memanfaatkan DDP dalam mengukur standar kualitas pembangunan desa. Mengambil kasus studi di Desa Neglasari, penelitian ini bermaksud mengukur kualitas pembangunan desa dan merekomendasikan kebijakan dan program yang tepat untuk memperbaiki kualitas pembangunan desa. Oleh karena itu, pertanyaan utama penulis dalam penelitian ini adalah bagaimana kualitas pembangunan desa berbasis Data Desa Presisi?

\section{PENDEKATAN TEORI}

\section{Kualitas Pembangunan Desa}

Desa merupakan sasaran utama pembangunan nasional karena desa adalah tempat berdiamnya target sasaran pembangunan, yakni keluarga (Sjaf et al. 2020). Kualitas pembangunan desa merupakan instrumen untuk mewujudkan kesejahteraan rakyat, sebagaimana amanat UUD 1945. Sjaf et al. (2020) juga menyebutkan hingga kini kerap terjadi penyangkalan warga desa terhadap membaiknya tingkat kesejahteraan, membaiknya kualitas sumberdaya manusia, dan lain sebagainya. Hal ini membuktikan kualitas pembangunan desa tidak sesuai dengan keadaan sesungguhnya. 
Membangun kemandirian desa dalam kerangka Desa Membangun dimulai dari proses perencanaan desa dan tata kelola program yang baik. Pembangunan yang efektif merupakan hasil dari perencanaan yang baik (Kessa 2015). Sejalan dengan hal tersebut, maka perencanaan pembangunan desa merupakan alat negara untuk mewujudkan pembangunan nasional. Negara telah berupaya merencanakan pembangunan desa dengan berbagai cara, diantaranya kebijakan Rencana Pembangunan Jangka Menengah Desa (RPJM Desa) dan Rencana Kerja Pemerintahan Desa (RKP Desa).

Namun, terdapat ketidaktepatan dalam implementasi perencanaan pembangunan desa, Sofuroh (2019) menuliskan 4 kelemahan mendasar Undang-Undang Nomor 25 tahun 2004 tentang Sistem Perencanaan Pembangunan Nasional, yakni: model perencanaan pembangunan hanya bertumpu di tangan eksekutif, yang mengakibatkan hilangnya prinsip serta semangat gotong royong dan mengedepankan individualisme; fakta mengenai substansi RPJM yang berbeda atau dikurangi dari RPJP, tidak terikat ketentuan satupun di dalam UUD RI Tahun 1945 atau undang-undang lainnya yang melarang hal tersebut; visi, misi dan program kerja Presiden terpilih ternyata dalam beberapa hal berbeda dengan visi, misi dan program kerja Kepala Daerah terpilih.

Maka, dapat terjadi perbedaan implementasi RPJM Nasional dengan RPJM Daerah; terakhir, Presiden maupun Kepala Daerah pengganti tidak memiliki kewajiban untuk melanjutkan program pembangunan yang telah atau sedang dijalankan tetapi belum sempat selesai oleh Presiden atau Kepala Daerah sebelumnya.

Berdasarkan Undang-Undang Dasar Tahun 1945 pasal 28, tersirat bahwa kualitas pembangunan desa di Indonesia dapat diukur melalui lima aspek kesejahteraan rakyat yang sebagaimana yang menjadi amanat pondasi negara, yakni: (1) sandang, pangan, papan; (2) pendidikan dan kebudayaan; (3) kesehatan, pekerjaan dan jaminan sosial; (4) kehidupan sosial, perlindungan hukum dan HAM; dan (5) infrastruktur dan lingkungan hidup. Di dalam masingmasing aspek kesejahteraan terdapat variabel pembentuk aspek.

Variabel pembentuk tersebut dapat didefinisikan dengan teori-teori maupun landasan ideal yang terkait. Adapun rangkuman dan pembahasan dari teori-teori dan landasan ideal pembentuk aspek tersebut diuraikan dalam poin sebagai berikut: (1) Sandang, Pangan, dan Papan: Manusia merupakan makhluk hidup yang memiliki kebutuhan pokok untuk dapat bertahan hidup. Kebutuhan pokok manusia adalah sandang, pangan dan papan. Pada hakikatnya, manusia dapat beraktivitas apabila kebutuhan pangannya tercukupi. Selain membutuhkan pangan, manusia membutuhkan sandang sebagai kebutuhan dasar. Sandang atau yang sering dikenal sebagai pakaian, bertujuan untuk menutupi bagian tubuh manusia yang diperlukan dalam kehidupan sehari-hari manusia. Kebutuhan dasar manusia yang ketiga adalah papan. Papan merupakan kebutuhan manusia untuk melindungi aktivitas manusia dan sebagai tempat beristirahat manusia. Rumah merupakan kebutuhan dasar bagi sebuah keluarga. Apabila rumah tidak dimiliki oleh sebuah keluarga maka keluarga itu dapat digolongkan ke dalam kelompok masyarakat miskin; (2) Pendidikan dan Kebudayaan, Pendidikan merupakan kebutuhan yang penting untuk masyarakat. Pendidikan tidak terbatas ruang dan waktu. Pemerintah Indonesia telah mengatur pendidikan rakyatnya dengan adanya UU Nomor 20 Tahun 2003 tentang Sistem Pendidikan Nasional yang menetapkan bahwa pemerintah dan pemerintah daerah menjamin terselenggaranya program wajib belajar minimal pada jenjang pendidikan dasar tanpa memungut biaya. Hal ini diperjelas dengan Peraturan Pemerintah Nomor 47 Tahun 2008 Tentang Wajib Belajar, yang mengatakan bahwa program wajib belajar diselenggarakan untuk memberikan pelayanan pendidikan dasar seluas-luasnya kepada warga negara Indonesia tanpa membedakan latar belakang agama, suku, sosial, budaya, dan ekonomi; (3) Kesehatan, Pekerjaan, dan Jaminan SosialPembangunan Negara Indonesia sedang dilakukan dengan harapan agar pembangunan ini dapat menciptakan dan meningkatkan kesejahteraan rakyat secara keseluruhan. Tanggung jawab pembangunan ini bukan hanya tanggung jawab pemerintah saja melainkan ini menjadi tanggung jawab seluruh masyarakat Indonesia. Kinerja dan keberhasilan dari pemerintah sangat erat dengan adanya partisipasi masyarakat dalam penyelenggaraan pemerintahan jika dikaitkan dengan penyaluran bantuan 
dana bergulir desa. Selain jaminan sosial yang berasal dari pemerintah, perlu diperhatikan pula bagaimana kondisi kesehatan dan pekerjaan masyarakat, karena hal tersebut merupakan penggerak roda pembangunan negara yang berkualitas. Pengetahuan tentang dimensi mata pencaharian masyarakat di suatu daerah merupakan potensi terhadap peningkatan kesejahteraan masyarakat yang berguna bagi perkembangan dan kemajuan daerah; (4) Kehidupan Sosial, Perlindungan Hukum dan HAM: Menurut Samosir (2018) kehidupan sosial, perlindungan Hukum dan HAM adalah aspek penting untuk menentukan tingkat kesejahteraan rakyat. Hukum merupakan kekuatan yang mengatur kehidupan sosial masyarakat agar teratur dan tertib, sementara HAM merupakan regulasi yang melindungi hak dan menjabarkan kewajiban masyarakat sebagai individu makhluk sosial. Salah Satu wujud perlindungan hukum dan HAM adalah pelayanan publik. Peraturan Presiden Nomor 59 Tahun 2017 tentang Pelaksanaan Pencapaian Tujuan Pembangunan Berkelanjutan di tingkat daerah, isu HAM dimasukkan ke dalam Panduan Penyusunan Rencana Aksi Daerah (RAD) dengan target-target seperti penurunan angka kematian ibu, penurunan angka kematian balita, penurunan angka AIDS/HIV, dan cakupan air minum serta sanitasi; dan (5) Infrastruktur dan Lingkungan Hidup: Peningkatan kesejahteraan masyarakat merupakan hakikat dari pembangunan nasional. Tingkat kesejahteraan merupakan cerminan dari tinggi rendahnya kualitas hidup keluarga.

Salah satu komunitas masyarakat yang membutuhkan peningkatan kesejahteraan, merupakan masyarakat nelayan. Nelayan pada dasarnya tinggal di wilayah pesisir dan memanfaatkan sumber Daya Alam laut sebagai mata pencaharian utamanya.

\section{Data Desa Presisi}

Sjaf et al. (2020) menyebutkan bahwa pemerintah kita sudah berinisiatif untuk menghasilkan satu data Indonesia. melalui Perpres Nomor 39 Tahun 2019 tentang Satu Data Indonesia. Namun sayangnya, inisiatif yang diusung tidak didukung dengan konsep atau pendekatan inklusif dalam implementasinya.

Tiga unsur penting yang dibutuhkan untuk menghasilkan sumber data desa yang menggambarkan secara aktual kondisi desa-desa di Indonesia adalah efisien, efektif, dan presisi. Efisien artinya pengambilan data tidak membutuhkan biaya besar; efektif artinya pengambilan, validasi, dan verifikasi data bisa dilakukan oleh warga desa dengan bantuan pihak luar desa (misal Perguruan Tinggi); dan presisi artinya data akurat dan tepat sebagaimana kondisi aktual di desa (Sjaf et al. 2020). Berdasarkan hal tersebut, Data Desa Presisi merupakan langkah tepat dalam menyelesaikan persoalan data desa yang perlu disegerakan.

Merujuk pada Sjaf et al. (2020) bahwa kehadiran UU Nomor 6 Tahun 2014 tentang Desa merupakan spirit dan momentum kehadiran Data Desa Presisi. Hak rekognisi dan subsidiaritas desa dapat digunakan sebagai respon tujuh isu strategis untuk membutuhkan Data Desa Presisi. Adapun Data Desa Presisi berupaya untuk menyambungkan ketujuh isu strategis tersebut dengan peran sebagai berikut. 
Tabel 1 Tujuh isu strategis desa yang membutuhkan data desa presisi

\begin{tabular}{|c|c|c|}
\hline No. & Isu Strategis & Peran Data Desa Presisi \\
\hline 1. & Penataan desa & Menyajikan peta tematik, dan menjamin transparansi serta akuntabilitas \\
\hline 2. & Perencanaan desa & $\begin{array}{l}\text { Memberikan akurasi data, membuka ruang partisipasi warga, mendorong } \\
\text { RPJAMDes, dan RKRDEs yang tepat kebutuhan desa }\end{array}$ \\
\hline 3. & Keriasama desa & $\begin{array}{l}\text { Menyajikan potensi desa secara utuh: vegetasi, sebaran komoditi, potensi } \\
\text { ekonomi kawasan, kelembagaan kawasan, pola kerjasama antar desa, RPKP }\end{array}$ \\
\hline 4. & Investasi masuk desa & $\begin{array}{l}\text { Menjadi dasar model pengembangan bisnis, sistem informasi desa/kawasan } \\
\text { perdesaan, dan promosi desa }\end{array}$ \\
\hline 5. & $\begin{array}{l}\text { BUADesal BUMDesa } \\
\text { Bersama }\end{array}$ & $\begin{array}{l}\text { Menjadi dasar model bisnis yang berbasis SDA lokal, sebaran unit usaha, } \\
\text { manajemen pengelolaan dan kecjasama }\end{array}$ \\
\hline 6. & Kejadian luar biasa & Menyajikan potensi bencana desa, rob, kerusakan ekosistem/ekologis \\
\hline 7. & Aset desa & $\begin{array}{l}\text { Menyajikan data posisi dan potensi asset, jumlah luasan serta peta sebaran } \\
\text { asset dan pemanfaatannya }\end{array}$ \\
\hline
\end{tabular}

Data Desa Presisi menggunakan pendekatan baru yakni Drone Participatory Mapping yang merupakan hasil sintesis tiga pendekatan, yaitu: spasial, sensus, dan partisipatif. Merujuk Sjaf et al. (2020) melalui partisipasi warga, data spasial yang diperoleh digunakan untuk menghasilkan data tematik persil (demografi, pendidikan, kesehatan, ekonomi, dan lain-lain), peta sesuai dengan kebijakan yang berlaku (administrasi, batas desa, infrastruktur, topografi, penggunaan lahan, dan lain-lain), verifikasi data potensi desa, estimasi maupun proksi pembangunan desa berbasis lahan, daya dukung desa, pembangunan infrastruktur, dan lainlain. Lebih dari itu, database yang diperoleh dari data spasial dapat dijadikan sebagai basis menyusun artificial intelligence Rencana Pembangunan Jangka Menengah Desa (RPJM Desa) dan Rencana Kegiatan Pembangunan Desa (RKP Desa).

Melalui pemahaman pendekatan DPM, maka perlu adanya implementasi yang mencakup alur kerja. Adapun implementasi pendekatan DPM, memiliki beberapa alur kerja yang harus dilakukan, meliputi sebagai berikut (Sjaf et al. 2020): (1) Pelatihan dan peningkatan kapasitas; (2) Pengambilan data citra desa; (3) Digitasi partisipasi; (4) Sensus dengan MERDESA Aplikasi; dan (5) Analisis Data Spasial dan Numerik. Keseluruhan data dan informasi dari citra drone maupun sensus disimpan ke dalam server yang menjadi big data desa di kemudian hari. Terdapat tiga jenis data yang dihasilkan melalui pendekatan DPM, yaitu: data citra (spasial) desa resolusi tinggi, data numerik, dan data deskriptif. Data citra desa diperoleh melalui penggunaan drone, sementara itu untuk kedua jenis data lainnya diperoleh melalui MERDESA Aplikasi dengan minimal 113 variabel yang terkategori ke dalam 5 aspek Kesejahteraan Rakyat menurut UUD Pasal 28 ditambah 1 Aspek Identitas sebagai kunci mengidentifikasi sasaran informasi. 
Tabel 2 Aspek dan variabel data tabular desa

\begin{tabular}{|c|c|c|}
\hline No. & Aspek & Variabel \\
\hline 1. & Identitas & $\begin{array}{l}\text { Kode Desa; Kode Bangunan; Keterangan Bangunan; Keterangan Bangunan } \\
\text { Tak Berpenghuni; Nama Responden; Kode KK; Nomor KK; Nama Kepala } \\
\text { Keluarga; Desa; Dusun; RW; RT; Alamat Rumah; Nomor HP; Jumlah } \\
\text { Anggota KK; Tanggal Lahir Kepala Keluarga; dan Jenis Kelamin, Nama } \\
\text { Kepala Rumah Tangga, Nama Tulang Punggung Keluarga. }\end{array}$ \\
\hline 2. & $\begin{array}{l}\text { Sandang, Pangan dan } \\
\text { Papan }\end{array}$ & $\begin{array}{l}\text { Makanan Pokok, Lauk Hewani, Lauk Nabati, Sayuran, Pelengkap, Buah- } \\
\text { buahan, Bumbu, Bahan Masak, Menu Makan, Sumber Air, Sumber Air } \\
\text { Minum, Biaya Belanja/bulan, Biaya Sandang, papan, dan hiburan, Frekuensi } \\
\text { Beli Baju, Frekuensi Makan/hari, Status Kepemilikan Rumah, Jenis Atas } \\
\text { Terluas, Jenis Dinding Terluas, Jenis Lantai Terluas, Jumlah Kamar Tidur, } \\
\text { Jamban (ada/tidak), Aset Lain. }\end{array}$ \\
\hline 3. & $\begin{array}{l}\text { Pendidikan dan } \\
\text { Kebudayaan }\end{array}$ & $\begin{array}{l}\text { Agama, Etnis, Partisipasi Sekolah, Ijazah Sekolah Terakhir yang dimiliki, } \\
\text { Biaya Pendidikan/bulan (Rp). }\end{array}$ \\
\hline
\end{tabular}

4. Kesehatan, Pekerjaan dan Jaminan Sosial

Akses ke lahan Pertanian, Status Lahan Pertanian, Bukti Kepemilikan Lahan, Luas Lahan dikelola, Riwayat Komoditas Lahan, Pekarangan untuk Pertanian, Luas Pekarangan, Riwayat Komoditas Pekarangan, Luas lahan yang tidak dikelola, Pekerjaan Utama, Jika berusaha sendiri, maka: Tempat / Lokasi Usaha, Jika berusaha sendiri: Jumlah Pekerja, Pekerjaan Sampingan, Keterampilan Usaha, Adakah Anggota Keluarga menjadi TKI, Negara Tujuan Anggota Keluarga TKI, Tabungan/Bulan (Rp), Sumber Pinjaman, Penggunaan KB, Jumlah Penyakit Berat, Keterangan Penyakit Berat, Jenis Disabilitas, JKN-KIS/BPJS, BPJS Ketenagakerjaan, Kartu Indonesia Pintar, Bantuan Pangan Non Tunai, Raskin, Kartu Keluarga Sejahtera, Program Keluarga Harapan, UPPKS, PNM \ekaar BUMN, KUR.

5. Kehidupan Sosial,

Akta Lahir, KTP, Keikutsertaan dalam kegiatan sosial di lingkungan, LSM/NGO, Kelompok Tani, Kelompok Nelayan, Kelompok Buruh, Perlindungan

Hukum dan HAM ORMAS, Koperasi/Lembaga Ekonomi Lokal, Frekuensi Refreshing

6. Infrastruktur dan

Lokasi Lahan Pertanian, Sumber Air Irigasi, Sumber Air Pekarangan, Lemari Es/Kulkas, Sepeda, Sepeda Motor, Mobil, Perahu, Perahu Motor. Kapal, Lingkungan Hidup Biaya Operasional Kendaraan Media Informasi, Tempat Membuang Sampah, Alat komunikasi, Jumlah Anggota yang menggunakan HP, Daya PLN, Biaya Listrik /bulan

Seluruh aspek dan variabel tersebut, disajikan dalam bentuk pertanyaan-pertanyaan dasar yang dijawab oleh setiap kepala keluarga atau salah satu anggota keluarga yang mewakili. Pertanyaan-pertanyaan tersebut bersifat jawaban terbuka maupun tertutup. Selanjutnya data deskriptif (kualitatif) meliputi: (1) data sejarah desa; (2) data pengaruh dan kedekatan kelembagaan desa; (3) data masalah; dan (4) data stratifikasi dan mobilitas sosial. Dijelaskan oleh Sjaf et al. (2020) bahwa Merdesa Aplikasi merupakan aplikasi untuk sensus keluarga.

\section{Rekomendasi Pembangunan Desa}

Perencanaan pembangunan desa yang baik adalah yang memberikan ruang untuk warga turut berpartisipasi. Pendekatan top down yang selama ini digunakan terbukti tidak tepat untuk pembangunan desa. Model pembangunan partisipatif akan memberdayakan masyarakat dalam membangun desanya. Oleh karena itu, dengan model partisipatif akan membangkitkan motivasi masyarakat untuk terlibat dalam setiap tahapan pelaksanaan program pembangunan desa (Nain 2019). Rekomendasi pembangunan desa dihasilkan dari hasil evaluasi kualitas pembangunan desa yang bentuk saran yang sistematis berbentuk kebijakan dan atau program.

\section{PENDEKATAN LAPANG}

\section{Metode Penelitian}

Penelitian ini menggunakan metode kuantitatif dengan pendekatan Drone Participatory Mapping atau DPM yang didukung dengan data kualitatif. Penelitian ini bersifat deskriptif dengan tujuan menggambarkan fenomena-fenomena lapangan. Penelitian deskriptif dapat 
mendeskripsikan keadaan dalam tahapan-tahapan perkembangannya yang tidak memanipulasi variabel-variabel bebas (Hamdi dan Bahruddin 2014).

Kemudian data kualitatif diperoleh melalui studi literatur, observasi lapangan, dan wawancara mendalam. Adapun studi literatur dilakukan pada buku, jurnal, maupun artikel yang terkait dengan konsep kualitas pembangunan desa dan DDP. Observasi lapang dilakukan dengan lebih detail dan teliti saat peneliti melaksanakan sensus DDP dan penelitian lanjutan pada bulan Juni 2021. Hal ini dilakukan guna mengamati langsung fenomena riil di lapang yang kaitannya erat dengan kondisi pembangunan desa. Wawancara mendalam dilakukan kepada informan saat penelitian lanjutan.

\section{Lokasi dan Waktu Penelitian}

Penelitian ini dilakukan di Desa Neglasari, Kecamatan Dramaga, Kabupaten Bogor. Pemilihan lokasi dilakukan secara purposive atau secara sengaja karena lokasi tersebut menjadi salah satu desa tempat pelaksanaan DDP di antara 12 desa/kelurahan lingkar Kampus IPB Dramaga. Waktu penelitian dilakukan pada bulan Januari 2021 hingga Mei 2021.

\section{Teknik Pengumpulan Data}

Data yang digunakan dalam penelitian ini adalah data primer. Data primer diperoleh menggunakan pendekatan DPM. Terdapat pelaksanaan penguatan kapasitas (capacity building) kepada warga desa sebelum data spasial dan data numerik dikumpulkan untuk memaksimalkan hasil pendekatan partisipatif. Data spasial desa diperoleh menggunakan instrumen drone, sementara data numerik desa diperoleh melalui instrumen Merdesa Aplikasi. Data primer yang digunakan dalam penelitian ini adalah database DDP Desa Neglasari dan informasi maupun literatur pendukung Desa Neglasari yang dihimpun oleh DDP.

\section{Teknik Pemilihan Responden dan Informan}

Terdapat dua subjek dalam penelitian ini, yaitu responden dan informan. Populasi yang diambil dari penelitian ini adalah masyarakat Desa Neglasari. Unit analisis dalam penelitian ini adalah kepala keluarga Desa Neglasari yang telah disensus. Berdasarkan data dari DDP Desa Neglasari, tercatat jumlah masyarakat Desa Neglasari adalah 10.110 jiwa. Pemilihan informan dilakukan secara sengaja (purposive) dilakukan pada bulan Juni 2021 kepada: 1. Pemerintah Desa, yakni Kepala Desa (kades), Sekretaris Desa (Sekdes); 2. Perwakilan Ketua RW dan Ketua RT; 3. Perwakilan masyarakat desa. Adapun kriteria informan tersebut adalah bagian dari masyarakat Desa Neglasari yang terlibat dalam proses DDP, guna memberikan informasi yang relevan dan dapat membantu peneliti dalam menjawab perumusan masalah penelitian ini.

\section{Teknik Pengolahan dan Analisis Data}

Data yang diperoleh dari penelitian ini berupa data kuantitatif dan kualitatif. Data kuantitatif diperoleh menggunakan pendekatan DPM berupa database kuesioner digital Merdesa Aplikasi. Kemudian, database tersebut dimasukkan dan diolah ke dalam Microsoft Excel 2019. Indikator dalam setiap variabel diuraikan dengan menggunakan skor untuk memberikan nilai dari jawaban-jawaban yang terdapat dalam kuesioner.

Setiap indikator dihitung frekuensi responden dalam keseluruhan jawaban sesuai dengan pilihan jawaban yang kemudian disajikan dalam bentuk persentase. Tahap selanjutnya pengolahan data adalah menghitung jumlah dan persentase jawaban responden. Data tersebut dianalisis menggunakan tabel frekuensi untuk melihat data awal responden pada masingmasing variabel secara tunggal.

Proses analisis penelitian data kualitatif merujuk pada Creswell (2014), antara lain: mengorganisasikan dan menyajikan data, membuat coding seluruh data, menggunakan koding sebagai bahan untuk membuat deskripsi, menghubungkan antar tema, dan memberi interpretasi dan makna tentang tema. Data kualitatif berupa gambaran umum Desa Neglasari dan informasi tambahan yang diperoleh dari Data Desa Presisi Desa Neglasari, wawancara mendalam, 
observasi, dan studi literatur. Tahap terakhir dalam analisis data kualitatif adalah interpretasi dan menarik kesimpulan untuk mendukung data kuantitatif.

\section{HASIL DAN PEMBAHASAN}

\section{Kualitas Pembangunan Desa Neglasari Berbasis Data Desa Presisi}

Berdasarkan penelitian yang dilakukan oleh penulis, kualitas pembangunan desa dikategorikan menjadi 3, yakni rendah, sedang, dan tinggi. Adapun hasil keseluruhan kualitas pembangunan Desa Neglasari berdasarkan lima aspek Data Desa Presisi adalah sebagai berikut.

Analisis kualitas pembangunan desa dengan standar kualitas pembangunan desa berdasarkan Data Desa Presisi memiliki hasil yang variatif. Hal ini disebabkan oleh jumlah jiwa atau KK yang memiliki skor tertinggi juga beragam, hal ini mencirikan adanya dinamika pembangunan yang tidak merata dan menyeluruh. Berdasarkan definisi operasional dan teori terkait, untuk mencapai kategori kualitas tinggi hasil persentase rasio pada setiap variabel di tingkat desa maupun RW harus memiliki persentase minimal sebesar 70\% dari total KK atau total jiwa. Selanjutnya untuk kategori kualitas sedang didefinisikan dari hasil persentase $40 \%-70 \%$ dari total KK atau penduduk, sementara untuk kategori kualitas rendah didefinisikan dari hasil persentase senilai $0 \%-39 \%$.

Tabel 3 Kualitas pembangunan Desa Neglasari berdasarkan Data Desa Presisi

\begin{tabular}{|c|c|c|c|c|c|}
\hline \multirow[b]{2}{*}{ Aspek } & \multirow[b]{2}{*}{ Variabel } & \multicolumn{2}{|c|}{$\begin{array}{l}\text { Standar Pengukuran } \\
\end{array}$} & \multirow[b]{2}{*}{ Hasil (\%) } & \multirow[b]{2}{*}{ Kualitas } \\
\hline & & $\begin{array}{c}\text { Skor } \\
\text { tertinggi } \\
(\mathrm{KK})\end{array}$ & Total $(\mathrm{KK})$ & & \\
\hline \multirow{4}{*}{$\begin{array}{c}\text { Sandang, } \\
\text { pangan, dan } \\
\text { papan }\end{array}$} & Frekuensi beli pakaian & 400 & 2.845 & 14,05 & Rendah \\
\hline & Frekuensi makan & 1.788 & 2.845 & 62,85 & Sedang \\
\hline & Scienghkapvsomenu & 315 & 2.845 & 11,07 & Rendah \\
\hline & $\begin{array}{l}\text { Kapovocilivkan } \\
\text { jamban }\end{array}$ & 2.432 & 2.845 & 85,48 & Tinggi \\
\hline \multirow{2}{*}{$\begin{array}{c}\begin{array}{c}\text { Pendidikan } \\
\text { dan } \\
\text { kebudayaan }\end{array}\end{array}$} & Partisipasi sckolah & $\begin{array}{l}2.123 \\
\text { Jiwa }\end{array}$ & 10.110 Jiwa & 21,00 & Rendah \\
\hline & Ijazah sekolah terakhir & $\begin{array}{l}1.841 \\
\text { Jiwa }\end{array}$ & 10.110 Jiwa & 18,21 & Rendah \\
\hline \multirow{3}{*}{$\begin{array}{c}\text { Keschatan, } \\
\text { pekerjaan, dan } \\
\text { jaminan sosial }\end{array}$} & Jumlah penyakit berat & 2.590 & 2.845 & 91,04 & Tinggi \\
\hline & Pekerjaan utama & $\begin{array}{l}3.187 \\
\text { Jiwa }\end{array}$ & 10.110 Jiwa & 31,52 & Rendah \\
\hline & $\begin{array}{l}\text { Penerima JKN- } \\
\text { KIS/BPJS }\end{array}$ & 1.706 & 2.868 & 59,48 & Sedang \\
\hline & Partisipasi organisasi & 183 & 2.845 & 6,28 & Rendah \\
\hline $\begin{array}{c}\text { Kehidupan } \\
\text { sosial, }\end{array}$ & Wreporvilikrkan KTP & $\begin{array}{l}6.829 \\
\text { Jiwa }\end{array}$ & 10.110 Jiwa & 67,55 & Sedang \\
\hline $\begin{array}{l}\text { perlindungan } \\
\text { hukum dan }\end{array}$ & thepopriblakan akta & 4.331 & 10.110 Jiwa & & Sedang \\
\hline HAM & kelahiran & Jiwa & & & \\
\hline $\begin{array}{l}\text { Infrastruktur } \\
\text { dan }\end{array}$ & Sumber air & 8 & 2.845 & 0,28 & Rendah \\
\hline $\begin{array}{l}\text { dan } \\
\text { lingkungan } \\
\text { hidup }\end{array}$ & $\begin{array}{c}\text { Tempat membuang } \\
\text { sampah }\end{array}$ & 1.014 & 2.845 & 35,64 & Rendah \\
\hline
\end{tabular}

Analisis kualitas pembangunan desa dengan standar kualitas pembangunan desa berdasarkan Data Desa Presisi memiliki hasil yang variatif. Hal ini disebabkan oleh jumlah jiwa atau KK yang memiliki skor tertinggi juga beragam, hal ini mencirikan adanya dinamika pembangunan yang tidak merata dan menyeluruh. Berdasarkan definisi operasional dan teori terkait, untuk mencapai kategori kualitas tinggi hasil persentase rasio pada setiap variabel di tingkat desa maupun RW harus memiliki persentase minimal sebesar $70 \%$ dari total KK atau total jiwa. Selanjutnya untuk kategori kualitas sedang didefinisikan dari hasil persentase $40 \%-70 \%$ dari total KK atau penduduk, sementara untuk kategori kualitas rendah didefinisikan dari hasil persentase senilai $0 \%-39 \%$. 
Tabel 3 Kualitas pembangunan Desa Neglasari berdasarkan Data Desa Presisi

\begin{tabular}{|c|c|c|c|c|c|}
\hline \multirow[b]{2}{*}{ Aspck } & \multirow[b]{2}{*}{ Variabel } & \multicolumn{2}{|c|}{ Standar Pengukuran } & \multirow[b]{2}{*}{ Hasil (\%) } & \multirow[b]{2}{*}{ Kualitas } \\
\hline & & $\begin{array}{c}\text { Skor } \\
\text { tertinggi } \\
(\mathrm{KK})\end{array}$ & Total (KK) & & \\
\hline \multirow{4}{*}{$\begin{array}{l}\text { Sandang, } \\
\text { pangan, dan } \\
\text { papan }\end{array}$} & Frekuensi beli pakaian & 400 & 2.845 & 14,05 & Rendah \\
\hline & Frekuensi makan & 1.788 & 2.845 & 62,85 & Sedang \\
\hline & $\begin{array}{l}\text { Welenglkagversmenu } \\
\text { makan }\end{array}$ & 315 & 2.845 & 11,07 & Rendah \\
\hline & $\begin{array}{l}\text { Kaponcilikikan } \\
\text { jamban }\end{array}$ & 2.432 & 2.845 & 85,48 & Tinggi \\
\hline $\begin{array}{l}\text { Pendidikan } \\
\text { dan }\end{array}$ & Partisipasi sckolah & $\begin{array}{l}2.123 \\
\text { Jiwa }\end{array}$ & 10.110 Jiwa & 21,00 & Rendah \\
\hline kebudayaan & Ijazah sekolah terakhir & $\begin{array}{l}1.841 \\
\text { Jiwa }\end{array}$ & 10.110 Jiwa & 18,21 & Rendah \\
\hline \multirow{4}{*}{$\begin{array}{l}\text { Keschatan, } \\
\text { pekerjaan, dan } \\
\text { jaminan sosial }\end{array}$} & Jumlah penyakit berat & 2.590 & 2.845 & 91,04 & Tinggi \\
\hline & Pekerjaan utama & $\begin{array}{c}3.187 \\
\text { Jiwa }\end{array}$ & 10.110 Jiwa & 31,52 & Rendah \\
\hline & $\begin{array}{l}\text { Penerima JKN- } \\
\text { KIS/BPJS }\end{array}$ & 1.706 & 2.868 & 59,48 & Sedang \\
\hline & Partisipasi organisasi & 183 & 2.845 & 6,28 & Rendah \\
\hline $\begin{array}{l}\text { Kehidupan } \\
\text { sosial, } \\
\text { perlindungan }\end{array}$ & Wreporilikakan KTP & $\begin{array}{c}6.829 \\
\text { Jiwa }\end{array}$ & 10.110 Jiwa & 67,55 & Sedang \\
\hline $\begin{array}{l}\text { hukum dan } \\
\text { HAM }\end{array}$ & $\begin{array}{l}\text { Whepowiblakikan akta } \\
\text { kelahiran }\end{array}$ & $\begin{array}{l}4.331 \\
\text { Jiwa }\end{array}$ & 10.110 Jiwa & 42,84 & Sedang \\
\hline $\begin{array}{l}\text { Infrastruktur } \\
\text { dan }\end{array}$ & Sumber air & 8 & 2.845 & 0,28 & Rendah \\
\hline $\begin{array}{l}\text { lingkungan } \\
\text { hidup }\end{array}$ & $\begin{array}{l}\text { Tempat membuang } \\
\text { sampah }\end{array}$ & 1.014 & 2.845 & 35,64 & Rendah \\
\hline
\end{tabular}

Merujuk pada tabel 3, dapat di deskripsikan bahwa pada aspek sandang, pangan, dan papan, variabel frekuensi beli pakaian memiliki kualitas rendah, frekuensi makan memiliki kualitas sedang, dengan kualitas rendah pada variabel kelengkapan menu makan, sementara pada variabel kepemilikan jamban, Desa Neglasari memiliki kualitas pembangunan yang tinggi. Selanjutnya, pada aspek pendidikan dan kebudayaan, variabel partisipasi sekolah dan variabel ijazah terakhir, keduanya memiliki kualitas rendah. Pada aspek ketiga, yakni kesehatan, pekerjaan, dan jaminan sosial, variabel jumlah penyakit berat memiliki kualitas tinggi, variabel pekerjaan utama memiliki kualitas rendah, dan variabel penerima JKN-KIS/BPJS berada pada kualitas sedang. Kemudian, pada aspek kehidupan sosial, perlindungan hukum dan HAM, variabel partisipasi organisasi masyarakat berada pada kualitas rendah, sementara variabel kepemilikan KTP dan kepemilikan akta kelahiran sama-sama memiliki kualitas sedang. Aspek terakhir, yakni infrastruktur dan lingkungan hidup memiliki kualitas rendah pada variabel sumber air maupun variabel tempat membuang sampah.

\section{Rekomendasi Perbaikan Kualitas Pembangunan Desa Neglasari}

\section{Rekomendasi Perbaikan Kualitas Sandang Pangan, dan Papan}

Berdasarkan pengukuran kualitas pembangunan Desa Neglasari pada aspek sandang, pangan, dan papan, memiliki hasil kategori yang beragam. Hasil pengukuran dengan kualitas tinggi hanya terdapat pada salah satu dari empat variabel, yakni variabel kepemilikan jamban. Adapun kualitas sedang terdapat pada variabel frekuensi makan per hari, sementara variabel frekuensi beli pakaian dan variabel kelengkapan menu makan termasuk kategori kualitas rendah.

Hasil pengukuran pada variabel frekuensi makan per hari masyarakat Desa Neglasari menunjukkan bahwa pola makan masyarakat belum mencapai kualitas yang tinggi. Meskipun sudah sebagian besar mengkonsumsi makan $\geq 3$ kali sehari, namun hal ini masih mencapai standar sedang. Berdasarkan pengamatan langsung peneliti, sebagian warga yang dijumpai masih acuh terhadap pola makan 3 kali sehari, faktor yang biasanya menyebabkan hal ini adalah kebiasaan tidak sarapan atau makan pagi, dan keterbatasan ekonomi. Maka dari itu, rekomendasi untuk perbaikan kualitas frekuensi makan per hari adalah program dan atau kebijakan yang bertujuan untuk peningkatan frekuensi makan keluarga menjadi minimal 3 kali sehari. Salah satu 
bentuk program yang peneliti rekomendasi adalah penyuluhan peningkatan pola makan dan pentingnya sarapan sebelum beraktivitas.

Sementara itu, hasil pengukuran pada variabel kelengkapan menu makan juga menunjukkan angka kualitas yang sangat rendah. Kelengkapan menu makan berkesinambungan dengan bagaimana gizi masyarakat Desa Neglasari. Data menunjukkan bahwa tidak ada satu pun RW dengan yang memiliki persentase menu makan lengkap yang sedang maupun tinggi. Berdasarkan observasi peneliti, hal ini dikarenakan sebagian masyarakat jarang mengkonsumsi buah-buahan pada kehidupan sehari-hari, selain itu, menu yang sering dimakan hanya lauk dan nasi atau sayur dan nasi. Maka dari itu, rekomendasi untuk perbaikan kualitas kelengkapan menu makan adalah program dan atau kebijakan yang bertujuan untuk peningkatan menu makan menjadi minimal menu lengkap. Saran dari peneliti, pemerintah harus segera menghimbau masyarakat untuk memperbaiki pola kelengkapan makan. Selain itu, diharapkan juga pemerintah dapat memberi bantuan pangan untuk memaksimalkan gizi masyarakat, terutama pada RW dengan hasil pengukuran yang sangat rendah.

Variabel frekuensi beli pakaian per tahun juga menunjukkan hasil yang rendah. Sebagian besar penduduk desa hanya memenuhi kebutuhan sandangan dengan membeli pakaian kurang dari 3 kali setahun. Berdasarkan observasi, hal ini dilatarbelakangi oleh faktor ekonomi penduduk. Maka dari itu, rekomendasi untuk perbaikan kualitas frekuensi beli pakaian per tahun adalah program dan atau kebijakan yang bertujuan untuk peningkatan frekuensi beli pakaian keluarga menjadi minimal 5 kali setahun.

\section{Rekomendasi Perbaikan Kualitas Pendidikan dan Kebudayaan}

Berdasarkan pengukuran kualitas pembangunan Desa Neglasari, aspek pendidikan dan kebudayaan memiliki kategori rendah pada variabel partisipasi sekolah dan variabel ijazah sekolah terakhir yang dimiliki. Kedua variabel tersebut diukur berdasarkan total keseluruhan penduduk yang berada di Desa Neglasari, yakni sejumlah 10.110 jiwa.

Hasil pengukuran variabel partisipasi sekolah dan variabel ijazah sekolah terakhir penduduk menunjukkan bahwa rendahnya kualitas pendidikan di Desa Neglasari. Sesuai data, sebagian besar penduduk desa berstatus tidak sedang bersekolah, selain itu, sebagian besar penduduk hanya memiliki ijazah sekolah tingkat SD/sederajat. Berdasarkan observasi peneliti, hal ini disebabkan oleh banyak faktor, namun yang paling banyak dijumpai adalah faktor ekonomi keluarga, yang menyebabkan tidak maksimalnya kualitas pendidikan anggota keluarga. Maka dari itu, rekomendasi untuk perbaikan kualitas partisipasi sekolah adalah program dan atau kebijakan yang bertujuan untuk peningkatan partisipasi sekolah menjadi minimal sedang bersekolah. Selanjutnya, rekomendasi untuk perbaikan kualitas ijazah sekolah yang adalah program dan atau kebijakan yang bertujuan untuk peningkatan tingkat sekolah yang ditempuh menjadi minimal lulus SMP. Salah satu saran program dari peneliti adalah penyuluhan pentingnya pendidikan dalam keluarga, terutama pada RW dengan hasil pengukuran yang sangat rendah. Selain itu, pemerintah desa juga disarankan untuk memberikan kebijakan berupa program bantuan beasiswa untuk menunjang masalah ekonomi warga yang kesulitan.

\section{Rekomendasi Perbaikan Kualitas Kesehatan, Pekerjaan, dan Jaminan Sosial}

Berdasarkan pengukuran kualitas pembangunan Desa Neglasari pada aspek kesehatan, pekerjaan, dan jaminan sosial, memiliki hasil kategori yang beragam. Hasil pengukuran dengan kualitas tinggi hanya terdapat di salah satu dari tiga variabel, yakni variabel jumlah penyakit berat keluarga. Adapun kualitas sedang terdapat pada variabel penerima JKN-KIS/BPJS, sementara variabel pekerjaan utama penduduk termasuk kategori kualitas rendah.

Hasil pengukuran pada variabel penerima JKN-KIS/BPJS menunjukkan bahwa kurang maksimalnya tingkat partisipasi warga dalam mengikuti program fasilitas kesehatan dari pemerintah. Pada dasarnya, program JKN-KIS/BPJS ini berguna untuk menunjang kesehatan penduduk desa, hal ini berkesinambungan dengan variabel jumlah penyakit berat keluarga. Maka dari itu, rekomendasi untuk perbaikan kualitas penerima JKN-KIS/BPJS adalah program dan atau 
kebijakan yang bertujuan untuk peningkatan partisipasi penerima JKN-KIS/BPJS menjadi penerima.

Selanjutnya, hasil ukuran variabel pekerjaan utama penduduk Desa Neglasari menunjukkan bahwa tingginya jumlah pengangguran di desa. Berdasarkan pengamatan peneliti, sebagian besar warga mengaku pekerjaan utamanya hanya sebagai buruh serabutan, yang tidak memiliki penghasilan tetap. Hal ini tentunya menjadi faktor utama permasalahan ekonomi keluarga di Desa Neglasari. Maka dari itu, rekomendasi untuk perbaikan kualitas pekerjaan utama penduduk adalah program dan atau kebijakan yang bertujuan untuk peningkatan partisipasi penduduk menjadi berstatus bekerja. Salah satu program yang disarankan oleh peneliti adalah program pemberdayaan SDM, untuk meningkatkan produktivitas penduduk.

\section{Rekomendasi Perbaikan Kualitas Kehidupan Sosial, Perlindungan Hukum dan HAM}

Berdasarkan pengukuran kualitas pembangunan Desa Neglasari, aspek kehidupan sosial, perlindungan hukum dan HAM memiliki kategori rendah pada variabel partisipasi organisasi, sementara variabel kepemilikan akta kelahiran dan variabel kepemilikan KTP memiliki kualitas dengan kategori sedang.

Hasil pengukuran pada variabel partisipasi organisasi penduduk menunjukkan bahwa rendahnya tingkat keikutsertaan penduduk desa dalam kegiatan organisasi. Hal ini tentunya berdampak pada keaktifan organisasi desa. Menurut observasi peneliti, hal ini sudah terjadi pada beberapa organisasi desa, yakni PKK (Pemberdayaan Kesejahteraan Keluarga) sudah tidak aktif menjalankan programnya lagi. Selain itu, masyarakat cenderung tidak mengikuti organisasi karena sibuk dengan pekerjaannya masing-masing. Maka dari itu, rekomendasi untuk perbaikan kualitas partisipasi organisasi adalah program dan atau kebijakan yang bertujuan untuk peningkatan partisipasi organisasi menjadi minimal berpartisipasi dalam organisasi masyarakat. Salah satu yang dapat dilakukan pemerintah menurut peneliti adalah melakukan edukasi pentingnya berorganisasi dan berkelembagaan dalam kehidupan sosial masyarakat.

Sementara itu, variabel kepemilikan KTP dan akta kelahiran menunjukkan hasil yang kurang maksimal, dan masih berada pada kategori kualitas sedang. Sebagian penduduk hanya memiliki KTP, namun tidak memiliki akta kelahiran, atau sebaliknya, dikarenakan faktor usia. Sebagian lainnya beralasan bahwa tidak memiliki akta kelahiran karena pada zaman kelahirannya tidak ada yang mengurus surat akta kelahirannya. Padahal, kedua identitas ini sangat penting untuk urusan administrasi. Maka dari itu, rekomendasi untuk perbaikan kualitas kepemilikan KTP penduduk adalah program dan atau kebijakan yang bertujuan untuk peningkatan kepemilikan KTP penduduk menjadi berstatus punya. Adapun rekomendasi untuk perbaikan kualitas kepemilikan akta kelahiran penduduk adalah program dan atau kebijakan yang bertujuan untuk peningkatan kepemilikan akta kelahiran penduduk menjadi berstatus punya.

\section{Rekomendasi Perbaikan Kualitas Infrastruktur dan Lingkungan Hidup}

Berdasarkan pengukuran kualitas pembangunan Desa Neglasari, aspek infrastruktur dan lingkungan hidup memiliki kategori rendah pada variabel sumber air keluarga dan variabel tempat membuang sampah. Kedua variabel tersebut diukur berdasarkan total keseluruhan keluarga yang berada di Desa Neglasari, yakni sejumlah 2.845 KK.

Hasil pengukuran pada variabel sumber air keluarga menunjukkan rendahnya penggunaan air PAM di Desa Neglasari. Sebagian besar penduduk menggunakan air sumur sebagai sumber air untuk memenuhi kebutuhan air sehari-hari rumah tangga. Berdasarkan observasi, penduduk memilih air sumur karena dianggap masih cukup bersih dan higienis untuk kebutuhan air seharihari. Selain itu, sebagian kecil rumah tangga masih menggunakan mata air sebagai sumber air utama. Maka dari itu, rekomendasi untuk perbaikan kualitas partisipasi organisasi adalah program dan atau kebijakan yang bertujuan untuk peningkatan sumber air yang digunakan keluarga.

Selanjutnya, variabel tempat membuang sampah keluarga juga memiliki hasil kualitas kategori rendah, hal ini dikarenakan sebagian warga mengaku memiliki kebiasaan membakar tumpukan sampah yang dinilai lebih praktis. Hal ini tentunya menunjukkan tingginya potensi pencemaran 
udara maupun tanah di Desa Neglasari. Maka dari itu, rekomendasi untuk perbaikan kualitas tempat membuang sampah keluarga adalah program dan atau kebijakan yang bertujuan untuk peningkatan tempat pembuangan sampah keluarga menjadi minimal di tempat pembuangan sampah. Pemerintah dihimbau untuk memberikan penyuluhan kepada penduduk untuk membuang sampah pada tempat pembuangan sampah.

\section{KESIMPULAN}

Berdasarkan hasil penelitian Kualitas Pembangunan Desa Berbasis Data Desa Presisi (Desa Neglasari, Kecamatan Dramaga, Kabupaten Bogor, Jawa Barat) dapat ditarik kesimpulan sebagai berikut: (1) Data Desa Presisi dapat menentukan standar kualitas pembangunan desa melalui pengukuran berdasarkan hasil persentase. Terdapat 5 aspek DDP dan 14 variabel yang menjadi standar pengukuran kualitas pembangunan, yakni: a) aspek sandang, pangan, dan papan dengan variabel frekuensi beli pakaian, frekuensi makan, kelengkapan menu makan, dan kepemilikan jamban; b) aspek pendidikan dan kebudayaan dengan variabel partisipasi sekolah dan ijazah sekolah terakhir; c) aspek kesehatan, pekerjaan, dan jaminan sosial dengan variabel jumlah penyakit berat, pekerjaan utama, dan penerima JKN-KIS/BPJS; d) aspek kehidupan sosial dengan variabel partisipasi organisasi, kepemilikan KTP, dan kepemilikan akta kelahiran; e) aspek infrastruktur dan lingkungan hidup dengan variabel sumber air dan tempat membuang sampah; (2) Pada aspek sandang, pangan, dan papan, kualitas dari variabel frekuensi beli pakaian dan variabel kelengkapan menu makan adalah rendah. Selanjutnya, variabel frekuensi makan memiliki kualitas sedang, dan variabel kepemilikan jamban memiliki kualitas tinggi. Pada aspek pendidikan dan kebudayaan, kualitas dari variabel partisipasi sekolah dan variabel ijazah sekolah terakhir memiliki kualitas rendah. Pada aspek kesehatan, pekerjaan, dan jaminan sosial, variabel jumlah penyakit berat memiliki kualitas tinggi, sementara variabel penerima JKN-KIS/BPJS memiliki kualitas sedang, dan variabel pekerjaan utama hanya memiliki kualitas rendah. Pada aspek kehidupan sosial, hukum, dan HAM, kualitas dari variabel partisipasi organisasi memiliki kualitas rendah, sementara variabel kepemilikan KTP dan variabel kepemilikan akta kelahiran sama-sama memiliki kualitas sedang. Pada aspek infrastruktur dan lingkungan hidup, kualitas dari variabel sumber air dan variabel tempat membuang sampah adalah rendah; (3) Rekomendasi perbaikan kualitas pembangunan Desa Neglasari adalah perlu adanya prioritas program dan atau kebijakan dari pemerintah desa untuk peningkatan kualitas pada variabel frekuensi beli pakaian per tahun (rendah), variabel kelengkapan menu makan (rendah), variabel partisipasi sekolah (rendah), variabel ijazah sekolah terakhir (rendah), variabel pekerjaan utama (rendah), variabel partisipasi organisasi (rendah), variabel sumber air (rendah), tempat membuang sampah (rendah), variabel frekuensi makan (sedang), variabel penerima JKN-KIS/BPJS (sedang), variabel kepemilikan KTP (sedang), variabel kepemilikan akta kelahiran (sedang).

\section{Saran}

Berdasarkan Berdasarkan hasil penelitian, terdapat beberapa saran dan masukan yang dapat diberikan, yakni sebagai berikut: (1) Perlu adanya peninjauan dari pemerintah desa mengenai penetapan standar pembangunan yang akurat dan berbasis data dalam perencanaan pembangunan Desa Neglasari; (2) Kualitas pembangunan Desa Neglasari berbasis DDP memiliki hasil yang cenderung rendah, maka dari itu perlu adanya program dan atau kebijakan yang difasilitasi oleh pemerintah desa sebagai agen pembangunan guna meningkatkan kualitas; dn (3) Pembangunan desa perlu berbasis data yang akurat agar tepat sasaran. Dan perlu adanya evaluasi rutin tahunan untuk mengukur pergerakan persentase kualitas Desa Neglasari. 


\section{DAFTAR PUSTAKA}

Ariesa P. 2019. Peran Elit Lokal Banten Dalam Pembangunan Desa [skripsi]. Bogor: Institut Pertanian Bogor.

Artaya IP. 2018. Dasar-Dasar Manajemen Operasi dan Produksi. Surabaya: Narotama University Press.

[BPS] Badan Pusat Statistik. Indeks Pembangunan Desa 2018. Jakarta: BPS.

Creswell JW. 2014. Research Design: Qualitative, Quantitative, and Mixed Methods Approaches. Ed ke-4. Los Angeles [LA]: SAGE Publications.

[Depernas] Dewan Perancang Nasional. 1959. Amanat Presiden Tentang Pembangunan Semesta Berencana. Jakarta: Dewan Perancang Nasional.

Dewi YPD, Purwidiani N. 2015. Studi Pola Konsumsi Makanan Pokok pada Penduduk Desa Pagendingan Kecamatan Galis Kabupaten Pamekasan Madura. Tata Boga. 4(3):108121. [diakses 25 Des 2020]. https://jurnalmahasiswa.unesa.ac.id/index.php/jurnal-tataboga/article/view/12987.

Farisa FC. 2021 Jan 10. Saat Megawati Sentil Jokowi soal Akurasi Data Desa. Kompas.com. [diakses $2021 \mathrm{Feb}$ 27]. https://nasional.kompas.com/read/2021/01/10/17232411/saatmegawati-sentil-jokowi-soal-akurasi-data-desa?amp $=1 \&$ page $=2$

Hamdi AS, Bahruddin E. 2014. Metode Penelitian Kuantitatif Aplikasi Dalam Pendidikan. Yogyakarta: deepublish.

Hendrik. 2011. Analisis Pendapatan Dan Tingkat Kesejahteraan Masyarakat Nelayan Danau Pulau Besar dan Danau Bawah di Kecamatan Dayun Kabupaten Siak Provinsi Riau. Perikanan dan Kelautan. 16(1):21-32. [diakses 25 Des 2020]. doi: 10.31258/jpk.16.01.\%25p.

Harmadi SHB, Suchaini U, Adji A. 2020. Indikator Pembangunan Desa di Indonesia: Ditinjau Dari Ketidaksesuaian Indikator Pengukuran Pembangunan Desa. Jakarta: TNP2K.

Indrati R, Gardjito M. 2014. Pendidikan Konsumsi Pangan. Jakarta: Kencana Prenadamedia Group.

[Kemendes PDTT] Kementerian Desa, Pembangunan Daerah Tertinggal, dan Transmigrasi. 2016. Peraturan Menteri Desa, Pembangunan Daerah Tertinggal, dan Transmigrasi Republik Indonesia Nomor 2 Tahun 2016 tentang Indeks Desa Membangun. Jakarta: Kemendes PDTT.

[Kemendes PDTT] Kementerian Desa, Pembangunan Daerah Tertinggal, dan Transmigrasi. 2019. Peraturan Menteri Desa, Pembangunan Daerah Tertinggal, dan Transmigrasi Republik Indonesia Nomor 17 Tahun 2019 tentang Pedoman Umum Pembangunan dan Pemberdayaan Masyarakat Desa. Jakarta: Kemendes PDTT.

[Kemendes PDTT] Kementerian Desa, Pembangunan Daerah Tertinggal, dan Transmigrasi. 2015. Perencanaan Pembangunan Desa. Jakarta: Kemendes PDTT.

[Kemendes PDTT] Kementerian Desa, Pembangunan Daerah Tertinggal, dan Transmigrasi. Peringkat Status Indeks Desa Membangun 2020. 2020. Jakarta: Kemendes PDTT.

[Kementerian PPN/Bappenas dan BPS] Kementerian Perencanaan Pembangunan Nasional/Badan Perencanaan Pembangunan Nasional dan Badan Pusat Statistika. 2014. Indeks Pembangunan Desa 2014. Jakarta: Kementerian PPN/Bappenas dan BPS. 
[Kementerian PPN/Bappenas] Kementerian Perencanaan Pembangunan Nasional/Badan Perencanaan Pembangunan Nasional. 2017. Peraturan Menteri Perencanaan Pembangunan Nasional/ Kepala Badan Perencanaan Pembangunan Nasional Nomor 1 Tahun 2017 Tentang Pedoman Evaluasi Pembangunan Nasional. Jakarta: Kementerian PPN/Bappenas.

[Kementerian PPN/Bappenas] Kementerian Perencanaan Pembangunan Nasional/Badan Perencanaan Pembangunan Nasional. 2019. Rencana Pembangunan Jangka Menengah Nasional 2020-2024. Jakarta: Kementerian PPN/Bappenas.

[Kementerian PUPR] Kementerian Pembangunan Umum dan Perumahan Rakyat. 2016. Pendataan Rumah Tidak Layak Huni. Jakarta: Kementerian PUPR.

Kessa W. 2015. Perencanaan Pembangunan Desa. Jakarta: Kementerian Desa, Pembangunan Daerah Tertinggal, dan Transmigrasi Republik Indonesia.

Kulla T, Rumapea P, Tampongaoy D. 2018. Kualitas Sumber Daya Manusia Dalam Meningkatkan Pembangunan Desa Tinggilbet Distrik Beoga Kabupaten Puncak Provinsi Papua. Administrasi Publik. 4(58):88-99. [diakses 26 Des 2020]. https://ejournal.unsrat.ac.id/index.php/JAP/article/view/19784/19383

Nain U. 2019. Pembangunan Desa Dalam Perspektif Sosiohistoris. Makassar [ID]: Garis Khatulistiwa.

[PRI] Pemerintah Republik Indonesia. 1945. Undang-Undang Dasar Republik Indonesia Tahun 1945. Jakarta: Sekretariat Negara.

[PRI] Pemerintah Republik Indonesia. 2000. Peraturan Pemerintah Republik Indonesia Nomor 102 Tahun 2000 Tentang Standardisasi Nasional. Jakarta: Sekretariat Negara.

[PRI] Pemerintah Republik Indonesia. 2008. Peraturan Pemerintah Republik Indonesia Nomor 47 Tahun 2008 tentang Wajib Belajar. Jakarta: Sekretariat Negara.

[PRI] Pemerintah Republik Indonesia. 2009. Undang-Undang Republik Indonesia Nomor 11 Tahun 2009 tentang Kesejahteraan Sosial. Jakarta: Sekretariat Negara.

[PRI] Pemerintah Republik Indonesia. 2014. Peraturan Pemerintah Republik Indonesia Nomor 43 Tahun 2014 Tentang Peraturan Pelaksanaan Undang-Undang Nomor 6 Tahun 2014 tentang Desa. Jakarta: Sekretariat Negara.

[PRI] Pemerintah Republik Indonesia. 2014. Undang-Undang Republik Indonesia Nomor 6 Tahun 2014 tentang Desa. Jakarta: Sekretariat Negara.

Samosir MS. 2018. Analisis Kesenjangan Pelayanan Perekaman E-KTP Di Desa Watuliwung Kecamatan Kangae Kabupaten Sikka. Projemen. 5(2):137-158. [diakses 26 Des 2020]. doi : 10.17605/OSF.IO/QK4BF.

Sari NM. 2019 Jan 23. Tujuan Pembangunan Nasional di Indonesia Sesuai UUD 1945. liputan6.com. Rubrik Citizen6. [diakses 24 Des 2020]. https://www.liputan6.com/citizen6/read/3877503/tujuan-pembangunan-nasional-diindonesia-sesuai-uud-1945

Silooy M. 2017. Analisis Faktor-Faktor Yang Mempengaruhi Tingkat Kemiskinan Absolut Masyarakat Pesisir (Nelayan) Di Desa Seilale Kecamatan Nusaniwe. Cita Ekonomika. 11(1):79-84. [diakses 25 Des 2020]. doi: 10.51125/citaekonomika.

Sjaf S, Elson L, Hakim L, Godya IM. 2020. Data Desa Presisi. Bogor (ID): IPB Press 
Sjaf S. 2019a Okt 16. Post-Truth dan Kebutuhan Data Desa Presisi. Geotimes.co.id. Rubrik Opini. [diakses $2021 \mathrm{Feb}$ 27]. https://geotimes.co.id/opini/post-truth-dan-kebutuhandata-desa-presisi/

Sjaf S. 2019b. Involusi Republik Merdesa. Bogor [ID]: IPB Press.

Sjaf S et al. 2021. Monografi Desa Neglasari. Bogor [ID]: LPPM IPB University.

Sjaf S. 2020a Jun 22. Membenahi Data Desa. Kompas.id. Artikel Opini. [diakses 2021 Feb 27]. https://www.kompas.id/baca/opini/2020/06/22/membenahi-data-desa/

Soetarto E, Sihaloho M. 2014. Pembangunan Masyarakat Desa. Jakarta: Universitas Terbuka.

Sofuroh FU. 2019 Sep 5. Basarah Ungkap 4 Kelemahan UU Sistem Perencanaan Pembangunan Nasional. Detik.com. Rubrik Berita.[diakses 2021 Mar 29]. https://news.detik.com/berita/d-4695388/basarah-ungkap-4-kelemahan-uu-sistemperencanaan-pembangunan-nasional

Sulvia WA, Nursalam LA. 2020. Faktor Penyebab Rendahnya Tingkat Pendidikan Masyarakat Di Desa Mabolu Kecamatan Loghia Kabupaten Muna. Penelitian Pendidikan Geografi. 5(1):82-89. [diakses 25 Des 2020]. doi: 10.36709/jppg.v5i1.11215.

Syukri M, Mahmut C. 2019. Analisis Dimensi Mata Pencaharian Dan Potensinya Dalam Meningkatkan Kesejahteraan Masyarakat Di Desa Tamuku Kecamatan Bone-Bone Kabupaten Luwu Utara. JEMMA. 2(1):89-101. [diakses 26 Des 2020]. doi : 10.35914/jemma.v2i1.146.

Yamit Z. 2010. Manajemen Kualitas Produk dan Jasa. Yogyakarta: Ekonisia.

Yuliati Y, Purnomo M. 2003. Sosiologi Pedesaan. Malang: Pustaka Utama. 